\title{
Monalizumab: inhibiting the novel immune checkpoint NKG2A
}

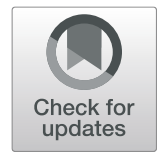

\author{
Thorbald van Hall ${ }^{1 *}$, Pascale André ${ }^{2}$, Amir Horowitz ${ }^{3}$, Dan Fu Ruan ${ }^{3}$, Linda Borst ${ }^{1}$, Robert Zerbib ${ }^{2}$, \\ Emilie Narni-Mancinellii, Sjoerd H. van der Burg ${ }^{1}$ and Eric Vivier ${ }^{2,4,5^{*}}$
}

\begin{abstract}
The implementation of immune checkpoint inhibitors to the oncology clinic signified a new era in cancer treatment. After the first indication of melanoma, an increasing list of additional cancer types are now treated with immune system targeting antibodies to PD-1, PD-L1 and CTLA-4, alleviating inhibition signals on T cells. Recently, we published proof-of-concept results on a novel checkpoint inhibitor, NKG2A. This receptor is expressed on cytotoxic lymphocytes, including NK cells and subsets of activated $C D 8^{+} T$ cells. Blocking antibodies to NKG2A unleashed the reactivity of these effector cells resulting in tumor control in multiple mouse models and an early clinical trial. Monalizumab is inhibiting this checkpoint in human beings and future clinical trials will have to reveal its potency in combination with other cancer treatment options.
\end{abstract}

Keywords: Cancer immunotherapy, CD8 T cells, NK cells, NKG2A, Inhibitory immune receptor, HLA-E/Qa-1

\section{Background}

Immuno-oncology has emerged as a revolution in cancer treatment. Unprecedented improvements in tumor control have been achieved with therapeutic blocking antibodies that release immune inhibitory 'checkpoints' (immune checkpoint inhibitors, ICIs). In particular, therapeutic monoclonal antibodies (mAbs) directed against the PD-1 (programmed-cell death protein 1)/PD-L1 (programmedcell death ligand 1) axis have been approved for use in monotherapy or combinations for several cancer indications [1-6]. Such treatments often yield sustained benefits, but strong responses are observed in only a minority of treated patients. Identification of predictive biomarkers for therapy response is subject of vigorous research at the moment and multiple factors have been determined. Among these factors are the number of $\mathrm{T}$ cells in the tumor and the total mutational load of tumor cells, indicating that ICIs depend on natural immunity targeting neoantigens presented by HLA molecules [7, 8]. Emerging lines of evidence also suggest that HLA class I genotype may predict tumor response to immune checkpoint blockade targeting PD-1

\footnotetext{
* Correspondence: T.van_Hall@lumc.nl; Vivier@ciml.univ-mrs.fr

${ }^{1}$ Department of Medical Oncology, Oncode Institute, Leiden University Medical Center, 2333, ZA, Leiden, the Netherlands

${ }^{2}$ Innate Pharma Research Labs, Innate Pharma, Marseille, France

Full list of author information is available at the end of the article
}

[9]. The studies found that maximal heterozygosity at HLA$A,-B$ and $-C$ loci contributes to improved overall survival following ICI therapy compared to patients that were homozygous at one HLA class I locus with the largest effects at $H L A-B$ and $-C$ [9]. Primary or acquired resistance to ICIs is observed in a substantial fraction of patients [10], making it difficult to identify predictive markers of efficacy or recurrence. Major efforts are therefore being made to identify resistance mechanisms aiming to counteract tumor escape and thereby improve current therapies. Among those are anti-inflammatory cytokines (e.g. transforming growth factor (TGF)- $\beta$, IL-6 or IL-10 [11]), inhibitory metabolic factors (e.g. prostaglandin E2 [12,13] and extracellular adenosine [14]), interferon signaling defects [15] and downregulation of classical HLA class I molecules [16], which are required for attack by tumor-specific cytotoxic $\mathrm{CD} 8^{+} \mathrm{T}$ lymphocytes. Loss of HLA class I expression on tumors is a well-established and common phenotype associated with many tumor types and has been linked to poor outcomes [16-25]. While the current understanding suggests that $\mathrm{CD}^{+} \mathrm{T}$ cells mediate the strongest anti-tumor response and that maximal heterozygosity is, by design, necessary to achieve optimal presentation of neoantigens, this narrative potentially underestimates the antitumor roles mediated by NK cells in response to 'immuno-edited' tumors. We recently reported that blockade of the immune checkpoint

(c) The Author(s). 2019 Open Access This article is distributed under the terms of the Creative Commons Attribution 4.0 International License (http://creativecommons.org/licenses/by/4.0/), which permits unrestricted use, distribution, and 
NKG2A recruits $\mathrm{CD}^{+} \mathrm{T}$ cell- as well as NK cell-reactivity to the stage [26, 27]. NKG2A is an inhibiting receptor expressed on subsets of cytotoxic lymphocytes and engages the non-classical molecule HLA-E [28, 29].

\section{Expression of the NKG2A ligands: HLA-E (human) and Qa- 1 (mouse)}

A view at the comprehensive tissue slide collection of the human protein atlas (www.proteinatlas.org) shows that HLA-E expression is, in general, ubiquitous but low. Exceptions are trophoblast cells in the placenta and ductal epithelial cells in the testis and epididymis, which display high levels of expression, suggesting a role for HLA-E in immune tolerance. Key factors of stabilization of the HLA-E protein at the cell surface are the availability of peptide ligands and proper function of the antigen processing machinery [30,31]. Interestingly, the accommodated peptides are rather monomorphic and include those which derive from the leader sequences of classical HLA class I proteins (named 'Qdm' in the mouse and 'VML9' in humans). Maximal expression of $H L A-A,-B$ and $-C$ alleles on tumors promotes higher HLA-E cell-surface expression through provision of VML9 peptides [32], resulting in increased inhibition of NKG2A-expressing NK cells and CD8 T cells. All alleles of $H L A-A$ encode a suitable HLA-E binding peptide, but polymorphisms across alleles drive differences in $H L A-A$ expression [33, 34] and thus vary the amount of available HLA-E binding peptide [35]. Conversely, $H L A-B$ is uniformly transcribed but has a dimorphism in its leader sequence at residue -21 encoding either a good binding methionine $(-21 \mathrm{M})$ or a poor binding threonine $(-21 \mathrm{~T})$ and thus varies whether or not it promotes HLA-E expression [36]. In mice, the inhibitory CD94/NKG2A receptor recognizes $\mathrm{Qa}-1$ complexes with leader peptides from $\mathrm{H}$ 2D alleles. Both HLA-E and Qa-1 were crystallized and fold like conventional MHC class I molecules, but show strong preference for the Qdm/VML9 peptide [37, 38].

In contrast to classical HLA molecules which are frequently lost, HLA-E protein levels are generally increased in cancer when compared to their healthy counterparts, as described in lung, kidney, pancreas, stomach, colon, head and neck, liver, melanoma, prostate, and rectal tumor tissues [26, 39-41]. Exact mechanisms influencing this differential expression remain to be determined. However, anti-tumor immunity and IFN- $\gamma$, in particular, promote HLA-E expression at the tumor cell surface [42, 43]. The HLA-E-peptide complex is recognized by the CD94/NKG2A heterodimer receptor that is expressed by over $50 \%$ of either the CD56 ${ }^{\text {bright }}$ immature or the CD56 ${ }^{\mathrm{dim}}$ mature NK cells from peripheral blood and on a subset of $\mathrm{CD}^{+} \mathrm{T}$ cells during chronic viral infections and in tumors [39, 44-46]. Engagement of CD94/NKG2A by HLA-E/Qa-1-expressing cells recruits the protein tyrosine phosphatase SHP-1 to the signaling synapse [47], resulting in the delivery of inhibitory signals to the effector cells and eventually inhibition of their immune activities [29, 43, 48]. NKG2A signaling appears to depend strictly on HLA-E/Qa-1 interactions and not on tonic signaling, since no detectable NK or $\mathrm{T}$ cell phenotype at steady-state has been observed [45, 49]. In head and neck, breast and non-small-cell lung cancer, invading NK cells express NKG2A [50, 51], and there is a correlation between high level of HLA-E expression and poor prognosis $[39,40,52,53]$. Taking together, these observations strongly supported the scientific rationale for the generation of anti-NKG2A blocking antibodies aiming at unleashing the suppressive effect of NKG2A on NK and $\mathrm{CD}^{+} \mathrm{T}$ cell activity.

\section{Anti-NKG2A blocking therapeutic monoclonal antibody promotes both $\mathrm{T}$ and NK cell immunity Blocking NKG2A signaling in mice releases both $T$ and NK cell effector functions}

Using a Qa-1 ${ }^{\mathrm{b}+}$ PD-L1 ${ }^{+}$A20 tumor model injected in $\mathrm{BALB} / \mathrm{c}$ mice, in which both $\mathrm{NK}$ and $\mathrm{CD} 8^{+} \mathrm{T}$ cells are required to control tumor growth, almost half of the $\mathrm{CD}^{+}$tumor infiltrating lymphocytes (TILs) expressed PD-1 and importantly, half of them expressed NKG2A [27]. A majority of NK TILs expressed NKG2A, but PD1 expression on NK cells was barely detectable. The tumor growth was controlled by combined blockade of NKG2A and the PD-1/PD-L1 (PD-x) axis, an effect that was dependent on both NK and CD8 T cells (Fig. 1). Moreover, the combined NKG2A and anti-PD-L1 blockade promoted tumor clearance in an additional mouse tumor model (RMA.Rae-1 $\beta$ ) and favored the generation of protective anti-tumor memory $\mathrm{CD}^{+} \mathrm{T}$ cells that protected the hosts upon re-challenge with the same tumor.

\section{Generation of monalizumab, a blocking anti-human NKG2A} $m A b$, to liberate $T$ and $N K$ cell effector functions

In human cancer samples, HLA-E was demonstrated widely expressed on the surfaces of several tumor types. Therefore, NKG2A blockade, either alone or in combination with other checkpoint inhibitors, might improve the anti-tumor efficacy of NK and CD8 ${ }^{+}$TILs in cancer patients. Monalizumab, a humanized anti-NKG2A blocking $\mathrm{mAb}$, increased degranulation and IFN- $\gamma$ production by $\mathrm{NKG}_{2} \mathrm{~A}^{+} \mathrm{NK}$ cell against HLA- $\mathrm{E}^{+}$target cells, thereby promoting NK cell effector functions [27]. It modestly increased the frequency of degranulating NKG2A ${ }^{+}$Flu-specific-CD8 $\mathrm{T}$ cells upon restimulation with Flu-specific-peptide in vitro. Importantly, when used in combination with durvalumab, an anti-PDL1 blocking $\mathrm{mAb}$, monalizumab exhibited additive effects promoting both $\mathrm{NKG}_{2} \mathrm{~A}^{+} \mathrm{PD}-1^{+} \mathrm{NK}$ and $\mathrm{CD} 8^{+} \mathrm{T}$-cell effector functions. Also, when combined with cetuximab, an anti-epidermal growth factor receptor (EGF-R) mAb which promotes antibody-dependent cell-mediated cytotoxicity (ADCC), monalizumab enhanced the NK cell-mediated 


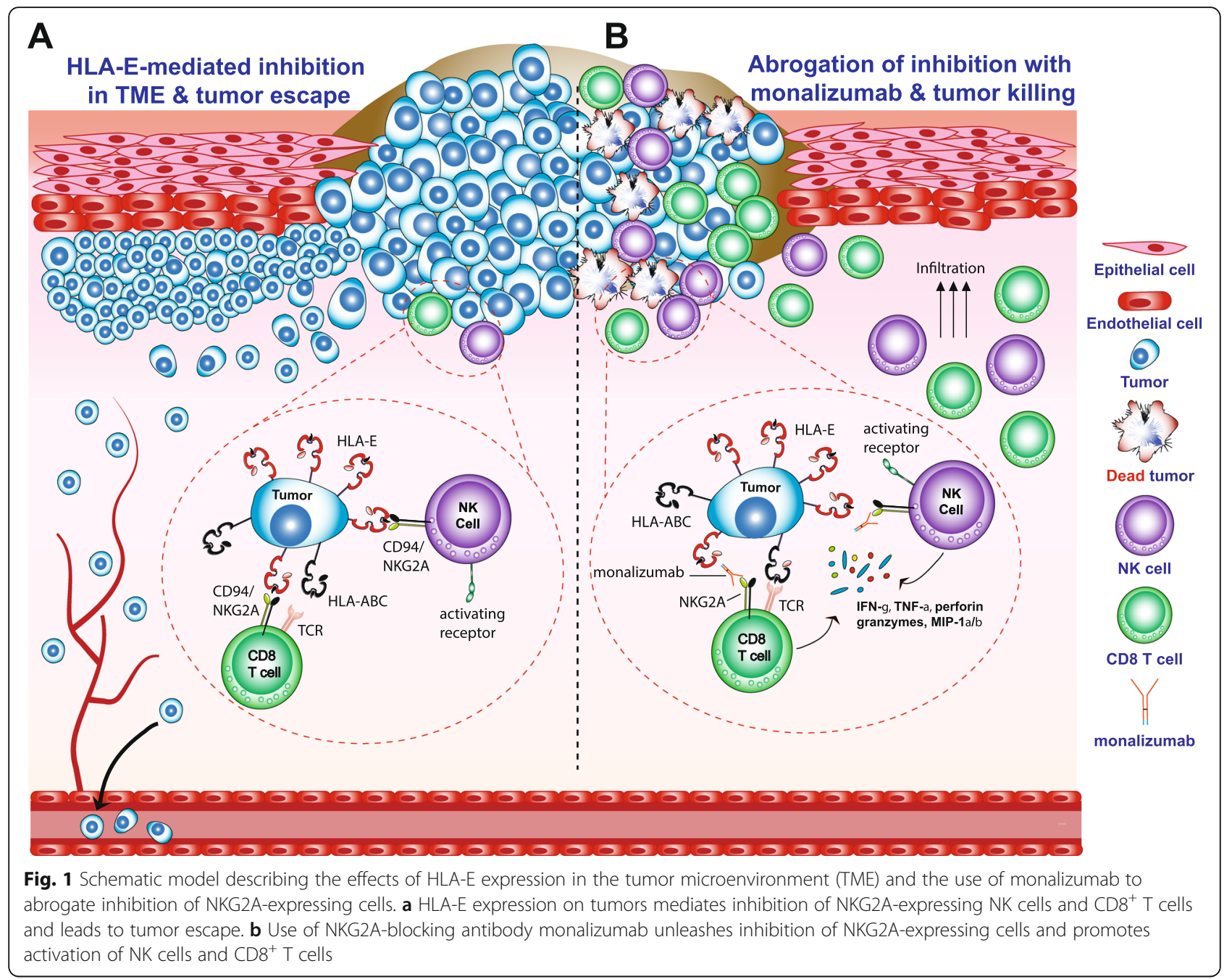

ADCC [27], suggesting that it would be interesting to investigate the effect of monalizumab to amplify the beneficial effects of other oncology treatments.

\section{Use of monalizumab, a blocking anti-human NKG2A mAb, in combination with other oncoimmunology compounds to treat cancer patients}

Following this rationale, evaluations of the efficacy and safety of monalizumab in cancer patients was conducted in phase II clinical trial using monalizumab in combination with cetuximab in patients with SCCHN (NCT026435509). In this interim report, an overall response rate (ORR) of $27.5 \%$ (95\% CI 16-41\%) was reported in 40 evaluable patients as compared to historical ORR of $13 \%$ observed for cetuximab monotherapy reported in earlier studies [27]. Monalizumab thus improved cetuximab response rates by unleashing NKG2A inhibition on lymphocytes, including NK cells. In this scenario, the mechanism of action of monalizumab likely consisted in the improvement of NK cell functions via antibody-dependent-cellular-cytotoxicity
(ADCC) by the tumor targeting antibody cetuximab, and not by NKG2A-expressing $\mathrm{CD} 8^{+} \mathrm{T}$ cells.

Recently, dose escalation of first-in-human combination of monalizumab plus durvalumab in cohort of patients with metastatic microsatellite-stable colorectal cancer (MSS-CRC) has been completed (NCT02671435). Preliminary data demonstrate a manageable toxicity profile and indicate that the combination has encouraging activity in patients with MSS-CRC, a population historically nonresponsive to PD-1/PD-L1 blockade.

\section{Blocking NKG2A turns cancer vaccines into effective therapies \\ $N K G 2 A$ is expressed on an unique CD8 $T$ cell subset}

In contrast to the rich literature of CD94/NKG2A receptors for NK cell biology, expression and function of NKG2A on adaptive immune cells is covered in paucity. In addition to NK cells, CD94/NKG2A is observed on subsets of innate lymphocytes, NKT cells, $\gamma \delta$ T cells and $\mathrm{CD}^{+} \alpha \beta \mathrm{T}$ cells. The frequencies of NKG2A expressing 
$\mathrm{CD}^{+} \mathrm{T}$ cells in blood of SCCHN patients was very low, in the range of $2-10 \%$, whereas up to $50 \%$ of NK cells expressed CD94/NKG2A [26]. Interestingly, frequencies in tumor infiltrating lymphocytes (TIL) were much higher for $\mathrm{CD}^{+} \mathrm{T}$ cells, indicating that NKG2A was induced in the tumor environment or that NKG2A-positive cells were selectively recruited there $[26,39,46]$. Previous literature suggested that $\mathrm{T}$ cell receptor triggering is required for induction of NKG2A and can be increased by IL-12 or TGF $\beta[54,55]$. $\mathrm{CD}^{+} \mathrm{T}$ cells recognizing tumor antigens indeed are more likely to display this inhibitory receptor [26]. CyTOF analysis of CD8 ${ }^{+}$TILs in cervical carcinoma samples interestingly suggested a preferential expression of NKG2A on $\mathrm{T}$ cells positive for the $\mathrm{E}$ cadherin binding $\alpha E \beta 7$ integrin. This $\mathrm{CD}_{103^{+}}$subset is associated with tissue residency, which is an epigenetically imprinted program mediating localization of lymphocytes to the tissues where they persist and patrol to protect organs for reoccurrence of pathogens [56]. The highly increased frequency of NKG2A in TIL versus blood $\mathrm{CD}^{+} \mathrm{T}$ cells and its higher expression on tissue resident cells versus other differentiation statuses of $\mathrm{CD}^{+} \mathrm{T}$ cells suggests an tissue-protective function for NKG2A on activated, antigen-specific lymphocytes [57-59]. However, whether these TILs represent real tissue-resident memory cells or active effector cells within tissues needs to be further unraveled. A recent study indeed report strong correlations between HLA-E expression in tumor lesions and frequencies of $\mathrm{NKG}_{2 \mathrm{~A}^{+}} \mathrm{CD}^{+} \mathrm{T}$ cells [60]. To what extent this subset differs from those expressing PD-1 remains to be clarified in future studies. In any case, PD-1 expression seems more widespread on lymphocytes in cancers than NKG2A expression, which seems to be limited to tumorattacking cytotoxic lymphocytes. Interestingly, frequencies of NKG2A expressing NK cells were rather comparable between blood and TIL and, moreover, between an immune reactive milieu induced by treatment and an immune silent milieu in untreated tumors [26]. NKG2A expression on other cytotoxic lymphocyte subsets, including type 1 innate lymphocytes (ILC1), NKT cells and $\gamma \delta \mathrm{T}$ cells, needs further investigation.

\section{NKG2A blockade empowers anti-tumor $\mathrm{CD}^{+} \mathrm{T}$ cell immunity}

NKG2A has been reported to regulate $\mathrm{CD}^{+} \mathrm{T}$ cell immunity to some viruses in that virus-driven immunopathology was limited and antiviral $\mathrm{T}$ cell responses were sustained by triggering NKG2A [44, 45, 61]. These mouse virus models implied a tempering role for overheated $\mathrm{CD}^{+} \mathrm{T}$ cell responses. In multiple cancer mouse models, NKG2A on $\mathrm{CD}^{+} \mathrm{T}$ cells functions as an immune checkpoint and blockade of the NKG2A/Qa-1 axis release the inhibitory signals (Fig. 1) [26]. In these models, $\mathrm{CD}^{+} \mathrm{T}$ cell immunity was induced by cancer vaccines, which were by themselves not strong enough to control tumor outgrowth. Pharmacological and genetic interruption of the NKG2A/Qa-1 interaction using blocking mAb and Qa-1 knockdown in tumor cells empowered these cancer vaccines and resulted in tumor regressions and durable clinical responses. These effects were not observed with NKG2A blockade alone, indicating a need for pre-existing antitumor $\mathrm{CD}^{+} \mathrm{T}$ cell immunity. Importantly, addition of PD-1 blockade instead of NKG2A blockade to cancer vaccines failed to improve survival of the mice, suggesting a differential role for these two checkpoints. The synergistic effect of NKG2A blocking antibody was demonstrated in four mouse tumor models and detailed analysis of the treated tumors revealed a strong increase of Qa-1 expression on tumor cells caused by T-cell derived IFN- $\gamma$ and higher frequencies of $\mathrm{NKG}_{2} \mathrm{~A}^{+} \mathrm{CD}^{+} \mathrm{T}$ cells. Together, these pre-clinical data strongly instigate translation of this combinatorial treatment to cancer types for which off-theshelf vaccines are available, like Human Papillomavirus (HPV) antigen comprising synthetic long peptide, RNA or DNA vaccines.

\section{Future perspectives \\ Critical involvement of NK cell responses for anti-tumor immunity}

The importance of intratumoral $\mathrm{CD}^{+} \mathrm{T}$ cells for immunotherapy with checkpoint blockers is well recognized $[7,8]$, but more recently an indirect role of NK cells was revealed [62]. The NK cell frequency appeared to determine stimulatory dendritic cell numbers in the tumor and correlates with checkpoint responsiveness and increased survival. Mechanistically, production of the cytokine FLT3LG by NK cells defined this NK-DC axis [62]. Independent studies reached similar conclusions in that NK cell-mediated recruitment of conventional type 1 DCs (cDC1), which are BATF3 and CLEC9A positive, is essential for immunotherapyresponsive tumors $[13,63]$. This type of immuneinflamed environment could be induced by TLR agonists, STAT1-activating signals and an anti-IL-10 antibody, leading to sensitization of tumors that displayed primary resistance to checkpoint blockade therapy $[13,63]$. Importantly, several intervention strategies for the recruitment and activation of NK cells are emerging and will enable exploitation of these lymphocytes $[64,65]$. Interestingly, cell cycle arrest and senescence, as induced by a combination of small kinase inhibitors, rendered tumor cells sensitive for NK cell attack and, moreover, another study recently revealed a role for the NKG2A-HLA-E axis in regulating immune-mediated clearance of senescent cells [66, 67]. Together, these studies indicate a plethora of opportunities to recruit NK cell immunity, and more specifically NKG2A blockade, into the field of cancer therapy. 


\section{Cancer vaccines might sensitize for NKG2A inhibition therapy}

Although interest in cancer vaccines waned long ago due to a sheer lack of objective clinical responses in hundreds of trials, they recently regained attention since novel platforms demonstrated efficacy to induce broad $\mathrm{CD}^{+}$and $\mathrm{CD}^{+}$anti-tumor $\mathrm{T}$ cell immunity, increase immune infiltration of human cancers and eradicate premalignant lesions [68]. Recent clinical trials with cancer vaccines eliciting $\mathrm{T}$ cell immunity to personalized neoantigens or cancer virus antigens demonstrated promising prospects of this approach [69-71]. Moreover, vaccination therapy seems to combine very well with immune checkpoint blockade in that relapsed SCCHN patients responded well to a combination of nivolumab and a HPV16 peptide vaccine [70]. The addition of this long peptide vaccine improved the overall response rate and median overall survival. In the light of our recent findings on NKG2A, clinical trials with monalizumab and cancer vaccines are promising, but need to elucidate efficacy of this combinatorial approach.

\section{$H L A$ class I expression regulates both $C D 8^{+} T$ cells and NK cells in the tumor microenvironment}

The human immune system relies on HLA class I to present antigens to $\mathrm{CD}^{+} \mathrm{T}$ cells while concurrently modulating NK cell inhibition and functional sensitization to tumors. Perhaps, the dual ability of HLA class I to regulate both $\mathrm{NK}$ cells and $\mathrm{CD} 8^{+} \mathrm{T}$ cells reflects differences in windows of immune activity, where NK cells lack the need for prior antigen-specific sensitization and can rapidly amplify the initial immune reaction $[13,62,72-76]$. Indeed, a recent study demonstrated increased NK cell infiltration in tumor regions of lung adenocarcinoma patients strongly associated with loss of heterozygosity (LOH) at the $H L A-C$ locus compared to tumor regions without $H L A-C \mathrm{LOH}$ [77].

Analyses of genetic variation in $H L A-A,-B$ and $-C$ genes indicate that human populations are divided into groups that are stratified by HLA-E expression (higher threshold for NK cell activation) and the presence or absence of KIR ligands (degree of NK cell education) that define whether NKG2A-expressing or KIR-expressing NK cells are dominantly activated in response to cytokines, Fc-receptor-mediated signaling, and to loss of HLA-E or KIR ligands on tumors and HIV-infected $\mathrm{CD}^{+} \mathrm{T}$ cells $[35,78,79]$. Building on these emerging principles, a study of acute myeloid leukemia (AML) patients treated with IL-2 immunotherapy revealed patients with $-21 \mathrm{M} H L A-B$ alleles had significantly better leukemia-free and overall survival compared to patients that were homozygous for $-21 \mathrm{~T} H L A-B$ alleles and found correlations with diminished expression of HLA-E on primary AML blasts [80].
Future studies should consider a comprehensive analysis of HLA class I expression and immunoediting of HLA genes in the germline and matched tumor tissues when considering alleles of HLA class I that are specifically lost (or even duplicated) and whether they promote high HLA-E expression and encode KIR ligands. The level of HLA-E expression and presence or absence of KIR ligands in germline tissue will determine the educational environment and subsets of NK cells that are trained to react to perturbed expression of HLA on tumors, which has been shown to vary extensively across cancers [81].

\section{CMV reactivation and adaptive NK cells in the tumor microenvironment}

Understanding the effects of cytomegalovirus (CMV) infection (and reactivation) is also important in settings of cancer immunotherapy for its ability to imprint NK cell phenotypes and functions and promote expansion of adaptive or "memory-like" NK cell subsets (range: 0-70\% of the total circulating NK cells) [82]. Such expansions of adaptive NK cells have been observed in approximately $40 \%$ of healthy, latently infected individuals. In CMV infected individuals, adaptive NK cells have enhanced capacities for antibody-dependent cellular cytotoxicity (ADCC) and are particularly responsive to modulation of HLA-C on the surface of tumor cells. In most instances, CMV infection and adaptive NK cells are established well before tumorigenesis. Thus, CMV infection and adaptive NK cells may play an unappreciated role in potentiating ADCC reactivity to antibodies targeting tumor antigens (and to auto-antibodies, potentially contributing to treatment-related autoimmune toxicities). Intriguingly, higher HLA-E expression may be preferred for exploiting adaptive NK cell functions for immunotherapies. Adaptive NK cells preferentially express the activating isoform of NKG2A, NKG2C, and its recognition of HLA-E elicits an activating signal. Adaptive NK cells also express selfKIR2DL receptors making them particularly poised for recognizing HLA-C. Thus, somewhat counter-intuitively, CMV seropositive patients with high cell-surface expression of HLA-E may experience added protection from expanding adaptive NK cells where the therapeutic mechanisms of action are aimed at ADCC or abrogating inhibition through HLA-C, e.g. with lirilumab.

\section{Conclusion}

$\mathrm{NKG}_{2} \mathrm{~A}^{+}$NK cells represent over $50 \%$ of peripheral blood NK cells and is also expressed on a subset of activated $\mathrm{CD}^{+} \mathrm{T}$ cells during chronic viral infections, such as human immunodeficiency virus (HIV) [35] and hepatitis C-virus (HCV) [83], and in tumors [26]. It is unclear why large proportions of $\mathrm{CD}^{+} \mathrm{T}$ cells remain NKG2A negative. André and colleagues showed that monalizumab can potentiate other ICI in a combination therapy, 
such as anti-PD-1/PD-L1 [27] and Van Montfoort and colleagues demonstrated efficacy in combination with cancer vaccines [26]. A central paradigm in current oncoimmunology is 'combinations' and future clinical trials will need to carefully determine which combination therapy provides the best results in the interest of our patients.

\section{Abbreviations \\ ADCC: Antibody dependent cellular cytotoxicity; AML: Acute myeloid leukemia; CMV: Cytomegalo Virus; CTLA-4: Cytotoxic T-Lymphocyte Associ- ated Antigen 4; CyTOF: Mass Cytometry by Time-of-Flight; HCV: Hepatitis C Virus; HIV: Human immunodeficiency virus; HLA: Human leukocyte antigen; HPV: Human papilloma virus; ICl: Immune checkpoint inhibitor; IFN- Y: Interferon $\gamma ;$ KIR: Killer cell Immunoglobulin Receptor; LOH: Loss of Heterozygosity; mAb: monoclonal Antibody; ORR: Overall response rate; PD- 1: Programmed Death 1; PD-L1: Programmed Death Ligand 1; SCCHN: Squamous cell carcinoma of the head and neck; SHP-1: Src Homology 2 domain Phosphatase 1; TGF- $\beta$ : Transforming Growth Factor $\beta$; TIL: Tumor infiltrating lymphocytes}

\section{Acknowledgements}

The authors like to acknowledge their colleagues who worked on the projects mentioned in this review.

\section{Authors' contributions}

TVH, PA, AH, RZ and ENM wrote the manuscript; all authors were involved in amendments and improvements in the text. $\mathrm{AH}$ generated the figure. All authors read and approved the final manuscript.

\section{Funding}

The E.V. laboratory at CIML and Assistance-Publique des Hôpitaux de Marseille is supported by funding from the European Research Council (ERC) under the European Union's Horizon 2020 research and innovation program (TILC, grant agreement No. 694502), the Agence Nationale de la Recherche including the PIONEER Project (ANR-17-RHUS-0007), Equipe labellisée "La Ligue" (Ligue Nationale contre le Cancer), MSDAvenir, Innate Pharma and institutional grants to the CIML (INSERM, CNRS, and Aix-Marseille University) and to Marseille Immunopole.

The SvdB laboratory received grants from the Dutch Cancer Society (20147146, 2014-6696) and is supported by the national Oncode Institute.

\section{Availability of data and materials}

Not applicable

\section{Ethics approval and consent to participate}

Not applicable

\section{Consent for publication}

Not applicable

\section{Competing interests}

P.A., R.Z. and E. V are employees of Innate-Pharma. The other authors declare no competing financial interests.

\section{Author details}

'Department of Medical Oncology, Oncode Institute, Leiden University Medical Center, 2333, ZA, Leiden, the Netherlands. "Innate Pharma Research Labs, Innate Pharma, Marseille, France. ${ }^{3}$ Department of Oncological Sciences, Precision Immunology Institute, Tisch Cancer Institute, Icahn School of Medicine at Mount Sinai, New York, NY 10029, USA. ${ }^{4}$ Aix Marseille Université, INSERM, CNRS, Centre d'Immunologie de Marseille-Luminy, Marseille, France. ${ }^{5}$ Service d'Immunologie, Marseille Immunopole, Hôpital de la Timone, Assistance Publique-Hôpitaux de Marseille, Marseille, France.
Received: 31 May 2019 Accepted: 26 September 2019

Published online: 17 October 2019

\section{References}

1. Baumeister SH, Freeman GJ, Dranoff G, Sharpe AH. Coinhibitory pathways in immunotherapy for Cancer. Annu Rev Immunol. 2016;34:539-73.

2. Chen DS, Mellman I. Elements of cancer immunity and the cancer-immune set point. Nature. 2017;541(7637):321-30.

3. Okazaki T, Chikuma S, Iwai Y, Fagarasan S, Honjo T. A rheostat for immune responses: the unique properties of PD-1 and their advantages for clinical application. Nat Immunol. 2013;14(12):1212-8.

4. Okazaki T, Honjo T. PD-1 and PD-1 ligands: from discovery to clinical application. Int Immunol. 2007:19(7):813-24.

5. Schumacher TN, Schreiber RD. Neoantigens in cancer immunotherapy. Science. 2015:348(6230):69-74.

6. Sharma P, Allison JP. Immune checkpoint targeting in cancer therapy: toward combination strategies with curative potential. Cell. 2015;161(2):205-14.

7. Gubin MM, Zhang X, Schuster H, Caron E, Ward JP, Noguchi T, Ivanova Y, Hundal J, Arthur CD, Krebber WJ, et al. Checkpoint blockade cancer immunotherapy targets tumour-specific mutant antigens. Nature. 2014; 515(7528):577-81.

8. Tumeh PC, Hanview CL, Yearley JH, Shintaku IP, Taylor EJ, Robert L, Chmielowski B, Spasic M, Henry G, Ciobanu V, et al. PD-1 blockade induces responses by inhibiting adaptive immune resistance. Nature. 2014:515(7528):568-71.

9. Chowell D, Morris LGT, Grigg CM, Weber JK, Samstein RM, Makarov V, Kuo F, Kendall SM, Requena D, Riaz N, et al. Patient HLA class I genotype influences cancer response to checkpoint blockade immunotherapy. Science. 2018;359(6375):582-7.

10. Sharma P, Hu-Lieskovan S, Wargo JA, Ribas A. Primary, adaptive, and acquired resistance to Cancer immunotherapy. Cell. 2017;168(4):707-23.

11. Konjevic GM, Vuletic AM, Mirjacic Martinovic KM, Larsen AK, Jurisic VB. The role of cytokines in the regulation of NK cells in the tumor environment. Cytokine. 2019;117:30-40.

12. Wang D, Dubois RN. Eicosanoids and cancer. Nat Rev Cancer. 2010;10(3):181-93.

13. Bottcher JP, Bonavita E, Chakravarty P, Blees H, Cabeza-Cabrerizo M, Sammicheli S, Rogers NC, Sahai E, Zelenay S, Reis e Sousa C. NK cells stimulate recruitment of $\mathrm{CDC1}$ into the tumor microenvironment promoting Cancer immune control. Cell. 2018;172(5):1022-37 e1014.

14. Vijayan D, Young A, Teng MWL, Smyth MJ. Targeting immunosuppressive adenosine in cancer (vol 17, pg 709, 2017). Nat Rev Cancer. 2017;17(12):765.

15. Benci JL, Xu B, Qiu Y, Wu TJ, Dada H, Twyman-Saint Victor C, Cucolo L, Lee DSM, Pauken KE, Huang AC, et al. Tumor interferon signaling regulates a multigenic resistance program to immune checkpoint blockade. Cell. 2016; 167(6):1540-54 e1512.

16. Garrido F, Aptsiauri N, Doorduijn EM, Garcia Lora AM, van Hall T. The urgent need to recover MHC class I in cancers for effective immunotherapy. Curr Opin Immunol. 2016;39:44-51.

17. Campoli M, Ferrone S. HLA antigen changes in malignant cells: epigenetic mechanisms and biologic significance. Oncogene. 2008;27(45):5869-85.

18. Garrido F, Algarra I. MHC antigens and tumor escape from immune surveillance. Adv Cancer Res. 2001;83:117-58.

19. Garrido F, Ruiz-Cabello F, Cabrera T, Perez-Villar JJ, Lopez-Botet M, DugganKeen M, Stern PL. Implications for immunosurveillance of altered HLA class I phenotypes in human tumours. Immunol Today. 1997;18(2):89-95.

20. Hicklin DJ, Marincola FM, Ferrone S. HLA class I antigen downregulation in human cancers: T-cell immunotherapy revives an old story. Mol Med Today. 1999:5(4):178-86.

21. Hiraki A, Fujii N, Murakami T, Kiura K, Aoe K, Yamane H, Masuda K, Maeda T, Sugi $K$, Darzynkiewicz Z, et al. High frequency of allele-specific downregulation of HLA class I expression in lung cancer cell lines. Anticancer Res. 2004;24(3a):1525-8.

22. Marincola FM, Jaffee EM, Hicklin DJ, Ferrone S. Escape of human solid tumors from T-cell recognition: molecular mechanisms and functional significance. Adv Immunol. 2000;74:181-273.

23. McGranahan N, Rosenthal R, Hiley CT, Rowan AJ, Watkins TBK, Wilson GA, Birkbak NJ, Veeriah S, Van Loo P. Herrero J, et al. Allele-specific HLA loss and immune escape in lung Cancer evolution. Cell. 2017;171(6):1259-71 e1211.

24. Mehta AM, Jordanova ES, Kenter GG, Ferrone S, Fleuren GJ. Association of antigen processing machinery and HLA class I defects with clinicopathological outcome in cervical carcinoma. Cancer Immuno Immunother. 2008;57(2):197-206. 
25. Seliger B, Cabrera T, Garrido F, Ferrone S. HLA class I antigen abnormalities and immune escape by malignant cells. Semin Cancer Biol. 2002;12(1):3-13.

26. van Montfoort N, Borst L, Korrer MJ, Sluijter M, Marijt KA, Santegoets SJ, van Ham VJ, Ehsan I, Charoentong P, Andre P, et al. NKG2A blockade potentiates CD8 T cell immunity induced by Cancer vaccines. Cell. 2018; 175(7):1744-55 e1715.

27. Andre P, Denis C, Soulas C, Bourbon-Caillet C, Lopez J, Arnoux T, Blery M, Bonnafous C, Gauthier L, Morel A, et al. Anti-NKG2A mAb is a checkpoint inhibitor that promotes anti-tumor immunity by unleashing both $\mathrm{T}$ and NK cells. Cell. 2018;175(7):1731-43 e1713.

28. Braud VM, Allan DS, O'Callaghan CA, Soderstrom K, D'Andrea A, Ogg GS, Lazetic S, Young NT, Bell Jl, Phillips JH, et al. HLA-E binds to natural killer cell receptors CD94/NKG2A, B and C. Nature. 1998:391:795-9.

29. Le Drean E, Vely F, Olcese L, Cambiaggi A, Guia S, Krystal G, Gervois N, Moretta A, Jotereau F, Vivier E. Inhibition of antigen-induced $T$ cell response and antibody-induced NK cell cytotoxicity by NKG2A: association of NKG2A with SHP-1 and SHP-2 protein-tyrosine phosphatases. Eur J Immunol. 1998; 28(1):264-76.

30. Aldrich CJ, DeCloux A, Woods AS, Cotter RJ, Soloski MJ, Forman J. Identification of a tap-dependent leader peptide recognized by alloreactive T cells specific for a class Ib antigen. Cell. 1994;79:649-58.

31. van Hall T, Oliveira CC, Joosten SA, Ottenhoff TH. The other Janus face of Qa-1 and HLA-E: diverse peptide repertoires in times of stress. Microbes Infect. 2010;12(12-13):910-8.

32. Lee N, Goodlett DR, Ishitani A, Marquardt H, Geraghty DE. HLA-E surface expression depends on binding of TAP-dependent peptides derived from certain HLA class I signal sequences. J Immunol. 1998;160(10):4951-60.

33. Ramsuran V, Hernandez-Sanchez PG, O'HUigin C, Sharma G, Spence N Augusto DG, Gao X, Garcia-Sepulveda CA, Kaur G, Mehra NK, et al. Sequence and phylogenetic analysis of the Untranslated promoter regions for HLA class I genes. J Immunol. 2017;198(6):2320-9.

34. Ramsuran V, Kulkarni S, O'Huigin C, Yuki Y, Augusto DG, Gao X, Carrington M. Epigenetic regulation of differential HLA-A allelic expression levels. Hum Mol Genet. 2015;24(15):4268-75.

35. Ramsuran V, Naranbhai V, Horowitz A, Qi Y, Martin MP, Yuki Y, Gao X, Walker-Sperling $V$, Del Prete GQ, Schneider DK, et al. Elevated HLA-A expression impairs HIV control through inhibition of NKG2A-expressing cells. Science. 2018;359(6371):86-90.

36. Yunis EJ, Romero V, Diaz-Giffero F, Zuniga J, Koka P. Natural killer cell receptor NKG2A/HLA-E interaction dependent differential Thymopoiesis of hematopoietic progenitor cells influences the outcome of HIV infection. J Stem Cells. 2007;2(4):237-48.

37. O'Callaghan CA, Tormo J, Willcox BE, Braud VM, Jakobsen BK, Stuart DI, McMichael AJ, Bell Jl, Jones EY. Structural features impose tight peptide binding specificity in the nonclassical MHC molecule HLA-E. Mol Cell. 1998;1:531-41.

38. Zeng L, Sullivan LC, Vivian JP, Walpole NG, Harpur CM, Rossjohn J, Clements CS, Brooks AG. A structural basis for antigen presentation by the MHC class Ib molecule, Qa-1b. J Immunol. 2012;188(1):302-10.

39. Gooden $M$, Lampen $M$, Jordanova ES, Leffers $N$, Trimbos JB, van der Burg $\mathrm{SH}$, Nijman H, van Hall T. HLA-E expression by gynecological cancers restrains tumor-infiltrating CD8 T lymphocytes. Proc Natl Acad Sci U S A 2011;108(26):10656-61.

40. Talebian Yazdi M, van Riet $S$, van Schadewijk A, Fiocco M, van Hall T, Taube C, Hiemstra PS, van der Burg SH. The positive prognostic effect of stromal CD8+ tumor-infiltrating T cells is restrained by the expression of HLA-E in non-small cell lung carcinoma. Oncotarget. 2016;7(3):3477-88.

41. van Esch EM, Tummers B, Baartmans V, Osse EM, Ter Haar N, Trietsch MD, Hellebrekers BW, Holleboom CA, Nagel HT, Tan LT, et al. Alterations in classical and nonclassical HLA expression in recurrent and progressive HPVinduced usual vulvar intraepithelial neoplasia and implications for immunotherapy. Int J Cancer. 2014;135(4):830-42.

42. Gustafson KS, Ginder GD. Interferon-gamma induction of the human leukocyte antigen-E gene is mediated through binding of a complex containing STAT1alpha to a distinct interferon-gamma-responsive element. J Biol Chem. 1996;271(33):20035-46.

43. Malmberg KJ, Levitsky V, Norell H, de Matos CT, Carlsten M, Schedvins K, Rabbani H, Moretta A, Soderstrom K, Levitskaya J, et al. IFN-gamma protects short-term ovarian carcinoma cell lines from CTL lysis via a CD94/NKG2Adependent mechanism. J Clin Invest. 2002;110(10):1515-23.

44. Moser JM, Gibbs J, Jensen PE, Lukacher AE. CD94-NKG2A receptors regulate antiviral CD8+ T cell responses. Nature immunol. 2002;3:189-95.
45. Rapaport AS, Schriewer J, Gilfillan S, Hembrador E, Crump R, Plougastel BF Wang Y, Le Friec G, Gao J, Cella M, et al. The inhibitory receptor NKG2A sustains virus-specific CD8(+) T cells in response to a lethal poxvirus infection. Immunity. 2015;43(6):1112-24.

46. Sheu BC, Chiou SH, Lin HH, Chow SN, Huang SC, Ho HN, Hsu SM. Upregulation of inhibitory natural killer receptors CD94/NKG2A with suppressed intracellular perforin expression of tumor-infiltrating CD8+ T lymphocytes in human cervical carcinoma. Cancer Res. 2005;65(7):2921-9.

47. Viant C, Fenis A, Chicanne G, Payrastre B, Ugolini S, Vivier E. SHP-1-mediated inhibitory signals promote responsiveness and anti-tumour functions of natural killer cells. Nat Commun. 2014:5:5108.

48. Kamiya T, Seow SV, Wong D, Robinson M, Campana D. Blocking expression of inhibitory receptor NKG2A overcomes tumor resistance to NK cells. J Clin Invest. 2019;129(5):2094-106.

49. Hu D, Ikizawa K, Lu L, Sanchirico ME, Shinohara ML, Cantor H. Analysis of regulatory CD8 T cells in Qa-1-deficient mice. Nat Immunol. 2004:5:516-23.

50. Habif G, Crinier A, Andre P, Vivier E, Narni-Mancinelli E. Targeting natural killer cells in solid tumors. Cell Mol Immunol. 2019;16(5):415-22.

51. Mamessier E, Sylvain A, Thibult ML, Houvenaeghel G, Jacquemier J, Castellano R, Goncalves A, Andre P, Romagne F, Thibault G, et al. Human breast cancer cells enhance self tolerance by promoting evasion from NK cell antitumor immunity. J Clin Invest. 2011;121(9):3609-22.

52. Andersson E, Poschke I, Villabona L, Carlson JW, Lundqvist A, Kiessling R, Seliger B, Masucci GV. Non-classical HLA-class I expression in serous ovarian carcinoma: correlation with the HLA-genotype, tumor infiltrating immune cells and prognosis. Oncoimmunology. 2016;5(1):e1052213.

53. de Kruijf EM, Sajet A, van Nes JG, Natanov R, Putter H, Smit VT, Liefers GJ, van den Elsen PJ, van de Velde CJ, Kuppen PJ. HLA-E and HLA-G expression in classical HLA class I-negative tumors is of prognostic value for clinical outcome of early breast cancer patients. J Immunol. 2010;185(12):7452-9.

54. Derre L, Corvaisier M, Pandolfino MC, Diez E, Jotereau F, Gervois N. Expression of CD94/NKG2-a on human T lymphocytes is induced by IL-12: implications for adoptive immunotherapy. J Immunol. 2002;168(10):4864-70.

55. Gunturi A, Berg RE, Crossley E, Murray S, Forman J. The role of TCR stimulation and TGF-beta in controlling the expression of CD94/NKG2A receptors on CD8 T cells. Eur J Immunol. 2005:35(3):766-75.

56. Masopust D, Soerens AG. Tissue-resident T cells and other resident leukocytes. Annu Rev Immunol. 2019:37:521-46.

57. Hombrink P, Helbig C, Backer RA, Piet B, Oja AE, Stark R, Brasser G, Jongejan $A$, Jonkers RE, Nota $B$, et al. Programs for the persistence, vigilance and control of human CD8(+) lung-resident memory T cells. Nat Immunol. 2016; 17(12):1467-78

58. Piet B, de Bree GJ, Smids-Dierdorp BS, van der Loos CM, Remmerswaal EB, von der Thusen JH, van Haarst JM, Eerenberg JP, ten Brinke A, van der Bij W, et al. CD8(+) T cells with an intraepithelial phenotype upregulate cytotoxic function upon influenza infection in human lung. J Clin Invest. 2011:121(6):2254-63

59. Savas P, Virassamy B, Ye C, Salim A, Mintoff CP, Caramia F, Salgado R, Byrne DJ, Teo ZL, Dushyanthen $S$, et al. Single-cell profiling of breast cancer T cells reveals a tissue-resident memory subset associated with improved prognosis. Nat Med. 2018:24(7):986-93.

60. Hamid MA, Wang R, al e:Enriched HLA-E and CD94/NKG2a interaction attenuates tumor-infiltrating CD8 T lymphocyte responses. CIR 2019, in press.

61. Zhou J, Matsuoka M, Cantor H, Homer R, Enelow Rl. Cutting edge: engagement of NKG2A on CD8+ effector T cells limits immunopathology in influenza pneumonia. J Immunol. 2008;180(1):25-9.

62. Barry KC, Hsu J, Broz ML, Cueto FJ, Binnewies M, Combes AJ, Nelson AE, Loo K, Kumar R, Rosenblum MD, et al. A natural killer-dendritic cell axis defines checkpoint therapy-responsive tumor microenvironments. Nat Med. 2018; 24(8):1178-91.

63. Zemek RM, De Jong E, Chin WL, Schuster IS, Fear VS, Casey TH, Forbes C, Dart SJ, Leslie C, Zaitouny A et al. Sensitization to immune checkpoint blockade through activation of a STAT1/NK axis in the tumor microenvironment. Sci Transl Med. 2019:11(501):eaav7816.

64. Gauthier L, Morel A, Anceriz N, Rossi B, Blanchard-Alvarez A, Grondin G, Trichard S, Cesari C, Sapet M, Bosco F, et al. Multifunctional Natural Killer Cell Engagers Targeting NKp46 Trigger Protective Tumor Immunity. Cell. 2019;177(7):1701.

65. Guillerey C, Huntington ND, Smyth MJ. Targeting natural killer cells in cancer immunotherapy. Nat Immunol. 2016;17(9):1025-36.

66. Pereira BI, Devine OP, Vukmanovic-Stejic M, Chambers ES, Subramanian $P$, Patel N, Virasami A, Sebire NJ, Kinsler V, Valdovinos A, et al. Senescent cells 
evade immune clearance via HLA-E-mediated NK and CD8(+) T cell inhibition. Nat Commun. 2019;10(1):2387.

67. Ruscetti M, Leibold J, Bott MJ, Fennell M, Kulick A, Salgado NR, Chen CC, Ho YJ, Sanchez-Rivera FJ, Feucht J, et al. NK cell-mediated cytotoxicity contributes to tumor control by a cytostatic drug combination. Science. 2018;362(6421):1416-22.

68. van der Burg SH, Arens R, Ossendorp F, van Hall T, Melief CJ. Vaccines for established cancer: overcoming the challenges posed by immune evasion. Nat Rev Cancer. 2016;16(4):219-33.

69. Hilf N, Kuttruff-Coqui S, Frenzel K, Bukur V, Stevanovic S, Gouttefangeas C, Platten M, Tabatabai G, Dutoit V, van der Burg SH, et al. Actively personalized vaccination trial for newly diagnosed glioblastoma. Nature. 2019;565(7738):240-5.

70. Massarelli E, William W, Johnson F, Kies M, Ferrarotto R, Guo M, Feng L, Lee JJ, Tran H, Kim YU, et al. Combining immune checkpoint blockade and tumor-specific vaccine for patients with incurable human papillomavirus 16related Cancer: a phase 2 clinical trial. JAMA Oncol. 2019;5(1):67-73.

71. Ott PA, Hu Z, Keskin DB, Shukla SA, Sun J, Bozym DJ, Zhang W, Luoma A, Giobbie-Hurder A, Peter L, et al. An immunogenic personal neoantigen vaccine for patients with melanoma. Nature. 2017;547(7662):217-21.

72. Barrow AD, Edeling MA, Trifonov V, Luo J, Goyal P, Bohl B, Bando JK, Kim $\mathrm{AH}$, Walker J, Andahazy $\mathrm{M}$, et al. Natural killer cells control tumor growth by sensing a growth factor. Cell. 2018;172(3):534-48 e519.

73. Glasner A, Levi A, Enk J, Isaacson B, Viukov S, Orlanski S, Scope A, Neuman T, Enk CD, Hanna JH, et al. NKp46 receptor-mediated interferon-gamma production by natural killer cells increases Fibronectin 1 to Alter tumor architecture and control metastasis. Immunity. 2018;48(1):107-19 e104.

74. Putz EM, Mayfosh AJ, Kos K, Barkauskas DS, Nakamura K, Town L, Goodall KJ Yee DY, Poon IK, Baschuk N, et al. NK cell heparanase controls tumor invasion and immune surveillance. J Clin Invest. 2017;127(7):2777-88.

75. Souza-Fonseca-Guimaraes F, Cursons J, Huntington ND. The emergence of natural killer cells as a major target in Cancer immunotherapy. Trends Immunol. 2019:40(2):142-58.

76. Chiossone L, Dumas PY, Vienne M, Vivier E. Natural killer cells and other innate lymphoid cells in solid tumors and hematological malignancies. Nat Rev Immunol. 2018; in press.

77. Rosenthal R, Cadieux EL, Salgado R, Bakir MA, Moore DA, Hiley CT, Lund T, Tanic M, Reading JL, Joshi K, et al. Neoantigen-directed immune escape in lung cancer evolution. Nature. 2019;567(7749):479-85.

78. Anfossi N, Andre P, Guia S, Falk CS, Roetynck S, Stewart CA, Breso V, Frassati C, Reviron D, Middleton D, et al. Human NK cell education by inhibitory receptors for MHC class I. Immunity. 2006;25(2):331-42.

79. Horowitz A, Djaoud Z, Nemat-Gorgani N, Blokhuis J, Hilton HG, Beziat V, Malmberg KJ, Norman PJ, Guethlein LA, Parham P. Class I HLA haplotypes form two schools that educate NK cells in different ways. Sci Immunol. 2016;1(3):eaag1672.

80. Hallner A, Bernson E, Hussein BA, Ewald Sander F, Brune M, Aurelius J, Martner A, Hellstrand K, Thoren FB. The HLA-B -21 dimorphism impacts on NK cell education and clinical outcome of immunotherapy in acute myeloid leukemia. Blood. 2019;133(13):1479-88.

81. Marin R, Ruiz-Cabello F, Pedrinaci S, Mendez R, Jimenez P, Geraghty DE, Garrido F. Analysis of HLA-E expression in human tumors. Immunogenetics. 2003;54(11):767-75.

82. Beziat V, Liu LL, Malmberg JA, Ivarsson MA, Sohlberg E, Bjorklund AT, Retiere C, Sverremark-Ekstrom E, Traherne J, Ljungman P, et al. NK cell responses to cytomegalovirus infection lead to stable imprints in the human KIR repertoire and involve activating KIRs. Blood. 2013;121(14):2678-88.

83. Zhang C, Wang XM, Li SR, Twelkmeyer T, Wang WH, Zhang SY, Wang SF, Chen JZ, Jin X, Wu YZ, et al. NKG2A is a NK cell exhaustion checkpoint for HCV persistence. Nat Commun. 2019;10(1):1507.

\section{Publisher's Note}

Springer Nature remains neutral with regard to jurisdictional claims in published maps and institutional affiliations.

\section{Ready to submit your research? Choose BMC and benefit from:}

- fast, convenient online submission

- thorough peer review by experienced researchers in your field

- rapid publication on acceptance

- support for research data, including large and complex data types

- gold Open Access which fosters wider collaboration and increased citations

- maximum visibility for your research: over $100 \mathrm{M}$ website views per year

At $\mathrm{BMC}$, research is always in progress.

Learn more biomedcentral.com/submissions 